\title{
Gezi Park Crisis
}

\author{
Ali Ekşi \\ Atatürk Medical Technology Vocational Training School, Ege University, Bornova, Izmir, 35040, Turkey
}

Received 27 August 2013

Accepted 12 December 2013

\begin{abstract}
The objective of this article is to evaluate the Gezi Park incident which started on 28 May 2013 and continued until the end of June in terms of crisis management. The reasons why a civil opposition act that started against the decision taken by the government regarding the environment transformed into a serious crisis due to an unmanageable process by the government will be questioned. The reasons for the incident and why it could not be prevented will be evaluated from the perspective of crisis management. Problem areas focusing especially on crisis communication during the crisis management process, the effect of messages given by the administrators along with the use of disproportionate force in deepening the crisis along with the lessons learned from the crisis will be evaluated. The most important factors that transformed the events starting with representation problem into a crisis have been communication problems and the disproportionate force used on the protesters. Turkey should develop a proactive approach in crisis management and should develop permanent solutions to solve the communication problem. The study is important since this was the first time that an environmentalist action transformed into a social movement causing a serious crisis in a country like Turkey.
\end{abstract}

Keywords: crisis management, crisis communication, disproportionate force, participation, representation problem.

\section{Introduction}

Turkey has reached a stability regarding growth and inflation during the past decade and the national income has increased from about three thousand to more than ten thousand dollars. Along with development targets, assertive projects are also brought to the agenda and serious structural reforms are made. In accordance with the EU inclusion targets, studies regarding public administration reform particularly localization and participation in the decision making processes have become current issues. In this process, it is expected that in parallel to economic development and structural reform, democratic governance will be used more effectively in decision making processes. On the other hand, there are still serious issues regarding inclusive participation which is one of the basic principles of democratic governance. Especially, mechanisms required to ensure the participation of the public to decision making processes regarding environment have not yet been fully formed ${ }^{1,2}$.

Gezi Park is a public park located in the center of Istanbul near the Taksim Square which is one of the important symbols of the Republic. Actually there were a military barracks in the park area during the Ottoman rule. The barracks was demolished in 1940 and the Gezi Park of today was built ${ }^{3}$. A decision was taken by the Istanbul Metropolitan Municipality Council in 2011 and it was decided to rebuild the military barracks in accordance with its original ${ }^{4}$. However, as the park which is one of the rare green areas in the center of Istanbul was opened to structuring, the intended use of the military barracks became a topic of discussion. The fact that the central government had stated many times that the barracks could be used as a shopping mall or a residence resulted in the increase of the reaction by nongovernmental organizations related with the environment ${ }^{5,6}$.

The perception and management method of the government regarding the Gezi Park incident which started as an "ecological civil opposition movement" became an important topic of discussion ${ }^{7}$. Especially the disproportionate force used on the activists during the first days of the protests along with the problems experienced by the government in managing the process resulted in the spreading of the protests to all corners of the country. The violence of violence prone groups that blended in with the activists along with the disproportionate force inflicted by the police combined to transform the incident into an unmanageable crisis ${ }^{8}$. The Gezi Park events started on 28 May 2013 and continued until the end of June. The after effects of the events continued in July as well. During the events, protest rallies were made in 79 of the total of 81 cities in Turkey and about two and a half million people participated in these protests. Over five thousand people were taken into custody during the events, five people died one of which was a police officer and about four thousand people got injured. The resulting financial harm on public and privately owned goods was about 100 Million $\$$.

The objective of this study is to evaluate the Gezi Park events in terms of crisis management. Answers will be sought regarding how a civil opposition movement that started against a governmental decision transformed into a social movement and became a 
serious crisis as a result of a process that was unmanageable by the government. The study also aims to examine the reasons why the crisis could not be managed by the government. The fact that an environmental movement due to a representation problem has for the first time caused a crisis of this magnitude in the region where Turkey is located in makes this study important.

In the first section, the restructuring process of crisis management in Turkey will be evaluated with its problem areas. In the second section, the reasons for the Gezi Park crisis will be evaluated along with the problem areas regarding public participation in environment related decision making processes. Whereas in the third section the management of the Gezi Park crisis and problems of management will be evaluated in the light of the lessons taken out of the crisis.

\section{Crisis Management in Turkey}

Crisis management in Turkey was executed by four different institutions in Turkey prior to 2009. Due to the problems that this scattered structuring in crisis management caused in establishing coordination between these institutions, these four different institutions were closed down with Law number 5902 issued on 29 May 2009 and the Prime Ministry Disaster and Emergency Management Presidency was established. Among the responsibilities of the Prime Ministry Crisis Management Center that was closed during this process were tasks related with prevalent violence actions for removing basic rights and freedoms along with the disruption of public order due to violence events. The job definition of the Prime Ministry Disaster and Emergency Management Presidency that was newly established during the restructuring process of public management was limited to natural and technological disasters. The responsibilities of the closed Prime Ministry Crisis Management Center regarding social events were not defined in this new institution $^{10,11}$.

Crisis management in Turkey is centralist and hierarchical. This may sometimes decrease the effectiveness of the institutions working in crisis management, causing conflicts of role and responsibilities among the institutions. Crisis management is carried out in a more reactive manner. There is especially a widespread notion that the endeavors of the rural organization of crisis management are limited to intervention only ${ }^{12}$. Actually, positive works are carried out during the restructuring of the relevant management regarding these problem areas. However, serious problems still prevail in the strengthening of the rural organizations and the prevention of events with a proactive approach ${ }^{13}$.
It is vital in crisis management that there be a spokesman that can form the link between management and public opinion while ensuring the trust of the public. This spokesman should have been appointed by the management to ensure consistent flow of information to the public and to provide coordination between crisis management and media. It is important that the spokesman can give messages that take into account the concerns while reassuring the public ${ }^{14,15}$. When the sample cases are evaluated, it is observed that there are no communication plans in the crisis management of Turkey and this causes new problems during times of crisis. In addition, the ineffective use of spokesmen during times of crisis and the inability to give the right messages at the right times may sometimes bring with it new crises. There are no governmental units for crisis communication within the corporate crisis management structuring of Turkey and there are also no corporate appointments made for professional level spokesmanship $^{13}$. In ordinary times, the speeches given by the deputy prime minister who is the government spokesperson or the party vice president who is also the Justice and Development Party (AKP) spokesman is followed closely when an explanation or opinion is expected from the government. However, the speeches made by these representatives may be quite different than what is stated by the Prime Minister even in ordinary times. Therefore, the President's speeches are given more importance as the voice of the management during ordinary or extraordinary times and the opinions of other officials are generally not enough to remove concerns or reassure the public ${ }^{16,17}$.

It is vital that the experiences gained during times of crisis are evaluated. The problems that occur during crisis management should be determined, the troubles regarding roles and responsibilities should be defined and the data formed should be shared with all parties related with crisis management ${ }^{18,19}$. The problem areas of crisis management in Turkey and the management performance are not evaluated effectively in Turkey and similar errors are repeated in consecutive cases of crisis. For each crisis, new reactive solutions are found to solve the problem under the conditions of that particular day. This result in the continuation of the failure in crisis management and the inability to transfer the experiences gained during crisis management to future crisis situations $^{13,20}$.

\section{The Reasons of the Gezi Park Crisis}

The lack of mechanisms for the declaration of suggestions and concerns for the section of the public who did not give any votes or who did not vote for the ruling parties may sometimes cause new problem areas and a representation problem. In time, this may cause a 
problem of trust to appear between the government and the citizens resulting in concerns related with whether the government will make decisions for the good of the public thereby effecting respect and trust for the administrators $^{21,22}$. Systems that do not form participatory mechanisms in government and systems that perceive every opposition movement as a threat to themselves will want to prevent the formation of effective non-governmental organizations. Conflicts of interest may arise in systems where participatory mechanisms and non-governmental organizations are not strong enough which in turn results in making the oppression and fear among the public to become more pronounced $^{23}$. In this section of the study, the problem areas in Turkey regarding the representation problem which is the most important reason of Gezi Park events will be handled.

Turkey is not a party to decision international agreements such as "Aarhus", Utrecht Protocol" and "Espoo" which make public participation in decision making processes more effective. The only democratic legal tool that the public can present its opinions and suggestions in a limited manner regarding environmental decision making processesis the Environmental Impact Assessment (EIA) processes. The EIA legislation in Turkey has been renewed four times since it was first issued on 7 February 1993 and there have been countless changes made on the issued regulations. Changes were made in the new EIA Legislation which was last issued on 17 July 2008 to increase public participation taking into account the EU EIA Directive. In addition, non-governmental organizations have gone to court many times stating that the issued EIA legislations have deviated from their aim of protecting the environment ${ }^{24,25}$. EIA exemption demand by the government still continues in projects that might have serious effects on the environment in Turkey. In addition, positive decisions might be taken for the EIA reports for some projects despite severe protests from the local public. The final change made in the EIA legislation along with the reaction of the administration against EIA decisions results in the formation of a perception that EIA is used mostly as a tool to convince the public instead of being a participatory tool ${ }^{26,27}$.

It is important that the citizens are informed by the government and that the citizens may demand to be informed by the government in order to ensure effective participation in decision making processes. Citizens can participate in decision making processes more actively and support sustainable growth when the society is informed sufficiently regarding the projects and is given the right to access information ${ }^{22,28}$. It cannot be stated that a systematic briefing is given to the public in Turkey especially for the decision making processes of large projects. The projects may sometimes be announced as "Mad Project" during election campaigns. The legal regulation regarding the information demand by the citizens is the "Right to Information Act" issued in 24 October 2003. Even though the law openly states that everyone has the right to obtain information, some difficulties may arise during implementation. Governmental organizations may sometimes refuse to give information without any justification even though there is an obligation stated by the law and sometimes a negative response may be given to the information demand by showing the $7^{\text {th }}$ Article of the Law as justification which states that the required information demand cannot bring any additional work or research load to the administration ${ }^{29,30}$.

It is possible to see some examples of public consultation in Turkish Public Administration which can be evaluated as a stage of participation in public administration. Special Provincial Administrations and municipalities can carry out public opinion polls and opinion researches to determine the opinions and thoughts of the public. This method is not used frequently and does not have a direct impact on decision making processes. Another application in which the public can find opportunities for participation at local government level is the city councils. Many municipalities in Turkey have city councils, however contrary to well-functioning examples all over the world, they are used more for counseling rather than active participation in decision making processes ${ }^{31}$.

The problem areas regarding public participation in decision making processes related with environment in turkey had attracted the attention of international public before. There are infringement decisions given by the European Court of Human Rights against Turkey due to the fact that public opinion is not taken in accordance with the standards during decision making processes ${ }^{32,33}$. The European Commission has emphasized both in 2011 and 2012 "Turkey Progress Reports" that the methods for taking public opinion regarding issues related with environment have not been made fully compatible and have not been carried into action ${ }^{34}$. In May 2013, the European Parliament Greens Group declared its environmental protection concerns regarding the large projects in Turkey and have criticized that some of these projects have been exempt from EIA processes ${ }^{35}$.

As mentioned abote, the main reason for the start of the Gezi Park events is representation problem. In addition, there are other factors that caused this representation problem to escalate rapidly and transform into a social event and crisis all over the country. The language used by the government in recent times while carrying out their activities caused serious reaction and concerns in a section of the society. The process that 
started when the President announced that one of their objectives is to raise a faithful generation during the education system change in2012 continued with the declaration by the President that abortion is murder ${ }^{36,37,38}$. Lastly, the name "Yavuz Sultan Selim" selected for the $3^{\text {rd }}$ Bosphorusbridge the foundation of which was laid on 29May 2013 which is mentioned in various historical resources as "Alewi Massacrer" resulted in harsh response especially from the Alawite community $^{39,40}$. Many statements given in 2012 and 2013 were perceived by a section of the society as intervention to their way of life and frankly these concerns were not sufficiently removed ${ }^{41}$. The part of the public that was discomforted by the declarations and messages of the President supported the Gezi Park events. It was striking that the study carried out by GENAR research company during the events pointed out that $58 \%$ of the activists declared the President as the cause of the events while $13,7 \%$ declared the government as the cause ${ }^{42}$.

\section{Gezi Park Crisis Management Process}

The activists organized via social media and started setting up tents in the camp and staged a sit-in on 28 May 2013 after a wall around the park was started to be demolished and some trees were started to be cut. On the morning of 30May 2013 at about five o'clock in the morning, police intervened to the group that refused to leave the park and resisted the police. The intervention caused more protesters to come to Gezi Park and its surroundings. On 31May 2013 the protests increased and the disproportionate force used on the protesters carried the events to the top in the agenda of the country and from there the protests expanded to cover the whole country. After this stage, the events were no longer an "ecological civil opposition" to administrative decisions and transformed into a multi-dimensional crisis ${ }^{7,43,44}$.

It is undoubtedly accepted by everyone that the problem of representation during the decision making processes regarding the environment was effective in the starting of these events. The fact that about $35 \%$ of the activists stated that they did not vote before along with the fact that among those who state to have voted before almost all declare to have voted for opposition parties supports the importance of representation problem in the transformation of the events to a crisis ${ }^{42}$. The problem areas regarding participation in decision making processes in Turkey were frequently discussed both nationally and internationally, however no one expected that a participation based representation problem could cause such a crisis ${ }^{45}$. The events might not have escalated to a crisis of this magnitude if Turkey had been able to solve its problem areas related with participation. The lack of a corporate body that will develop proactive management models and strategies during times of crisis caused by social movements was greatly felt during these events ${ }^{46,47}$.

Even though the problems that it caused are well known, the inability to prevent the crisis and how the crisis is managed are topics of discussion. The most important problem area in crisis management is the lack of a spokesman appointed to provide efficient communication with the public and the inability to give the right messages at the right time. As the events continued, Istanbul Administrative Court adopted a motion for the stay of execution on 31May 2013 for the lawsuit filed against the barracks project planned for the park. This court order was actually seen by many as a positive development that could decrease the intensity of the events ${ }^{48}$. Despite the positive messages given on the same day by the government spokesperson regarding the court order and statements meaning excuses from the protesters for the disproportionate intervention on the first day of the events, the President gave messages criticizing the decision given by the court. From then on, the public opinion started to take into consideration the declarations of only the President among the statements made by the relevant administrations. The information or messages given by other administrators were not sufficient in reassuring ${ }^{49}$. The President preferred to make statements during the rallies that his party decided to start as a response to the events. The statements declared during the rallies held in large cities of Turkey with the participation of hundreds of thousands of people were more like political messages for party members rather than aiming to solve the problem ${ }^{50,51}$.

Throughout the crisis management period, a proper communication with the public could not be established and the right messages were not given at the right time. The Mayor of Istanbul who was the local administrator for the location that the events took place in did not make any declarations for the first four days ${ }^{45}$. This caused the intensity of the events to increase. The President got together with non-governmental organizations which could be thought of as one of the parties of the Gezi Park events on 12 June 2013 that is 15 days after the start of the events. The most important messages that came out of that meeting were the decisions to postpone the barracks project planned for Gezi Park until the ongoing court gave an order and to consult public opinion even if the court favored the project. These messages that were for the most part accepted among the public were late in timing. Identifying the protesters as marginal along with definitions of political identity resulted in making crisis management more difficult instead of solving the problem $^{52}$. Studies carried out by survey companies during the events indicated that the vast majority of the 
protesters did not have any political identity. The study carried out by KONDA Survey Company during the events put forth that about $80 \%$ of the protesters were not members of any association or party and that the Gezi Park protests were their first protest for $45 \%$ of the protesters ${ }^{53}$. Especially the messages that had to be given by the administration during the first days of the protests should have been aimed to secure environmental protection approaches and to solve representation problem instead of being of political content.

In addition to the problem areas in crisis communication, the fact that the vast majority of visual media did not broadcast any of the events during the first days of the events was thought of as autocensorship and thus caused public response. This silence in visual media resulted in an increased use of social media. The study carried out by KONDA during the events put forth that about $80 \%$ of the participants followed news related with the events in social media and the internet ${ }^{53}$. From time to time the unreal and exaggerated posts in social media caused various speculations to occur and most of the time made crisis management more difficult ${ }^{54,55}$. The administration had to be more transparent during crisis management and should have strived to share real information with the public in a systematic manner in order to prevent speculations.

Various media institutions were also targeted by the protesters during the events. Protests were made in front of the buildings of some of the largest media institutions $^{56}$. In Turkey, there is a serious mistrust in the public regarding the media broadcasts made especially for the environment. Undoubtedly, the Gezi Park events should have had negative impact on media trust. When this is evaluated for future crisis events from the perspective of crisis management, it might have a negative impact on the efficient use of media which is an important means of acquiring information during crisis management ${ }^{13}$.

Another topic of discussion in crisis management was the occasional use of disproportionate force on the protesters. The use of disproportionate force can along with the problems in crisis communication be shown to be one of the two factors that deepened the crisis and made it difficult to manage ${ }^{57,58,59}$. Even though the protests started as an environment protection protest, the study carried out by KONDA during the events puts forth that only $15 \%$ of the protesters have explained their participation with reasons related to the environment whereas about \% 50 showed the disproportionate use of force by the police as the main reason. The occasional disproportionate force used by the police went out of control with the effect of groups inclined to use violence and quickly transformed into rallies against the government ${ }^{53}$.

Whereas the reason for the crisis was accepted by a section of the country as a representation problem, the lessons that the administration learned from this crisis are open to discussion. First, there is a widespread opinion among the administration that the events started with the support of outside forces to pave the way to a coup $^{60,61}$. Even if these opinions are completely true, when events are evaluated from a risk management perspective, the government first had to strengthen their own weak spots. The attitude of the government following the events unfortunately shows that the problem of representation has not been clearly understood. The only non-governmental organization that embraced the civil opposition since the beginning of the events, the "Taksim Solidarity Platform" was evaluated as an illegal organization in the summary of proceedings prepared by the Istanbul Directorate of Security $^{62}$. The members and administrators of the association were taken into custody ${ }^{63}$. The authorities of the "Union of Chambers of Turkish Architects and Engineers" which is one of Turkey's largest trade bodies that supported the events since the beginning that would allow participation in decision making processes were taken away with a proposal in the assembly and its financial power was decreased by taking away its income. This was evaluated by a section of the community as response to the Gezi Park events ${ }^{64}$.

The most important suggestion regarding the solution of the representation problem following the crisis was made by the Istanbul Metropolitan Municipality Mayor. It was stated in the suggestion that public opinion was going to be taken for all projects to be carried out by the municipality. However, according to the current laws this can only cover consulting the public and would definitely not be sufficient to ensure the efficient participation of the public in decision making processes. Serious reforms should be made in legal regulations and corporate structuring in order to solve the representation problem. In addition, the acceptance of standards that have been shaped in the international arena which might aid in the solution of the representation problem in environmental problems should be discussed more seriously.

It is widely accepted by the vast majority of the public that the inability to establish the right communication and the use of disproportionate force are two of the most important factors that deepened the crisis and made it unmanageable ${ }^{44,65}$. However, these problem areas in crisis management have not been clearly accepted by the government after the crisis. Especially among the government members, there are those who see excessive force as unnecessary and think that it makes a big thing out of such events along with 
those that state just the opposite ${ }^{66,67}$. Suggestions related to the solution of problems in crisis management are developed specific to Gezi Park events; for instance the suggestions for the solution of the chronic communication problem in crisis management are not even mentioned ${ }^{68}$. Turkey crisis management should discuss the lessons taken from this event more seriously and carry out studies to find permanent solutions to the problem areas in order to put an end to the after effects of the Gezi Park crisis and to ensure that similar mistakes are not made again during the possible events that might occur in the future.

\section{Conclusion}

Gezi Park events started as an ecologic civil opposition movement against a decision taken by the government but has propagated to the whole country as a rights and freedom movement since it was not perceived and managed properly by the administration. The main reason for the events is the representation problem arising due to lack of participation of the public in decision making processes. Whereas the inability to establish proper communication with the protesters and the disproportionate force used on the protesters during the first days of the events have transformed the events into a crisis. The coupling of the violence of violence inducing groups that mixed in with the protesters along with the use of disproportionate force has resulted in transforming the events into an uncontrollable crisis. The Gezi Park events showed that the social events can turn into major crises if they are not managed properly. Turkey should solve this representation problem in order to avoid experiencing the same crises again. The existing problems in crisis management should be evaluated by taking into account the Gezi Park Crisis example. Permanent solutions should be developed for problem areas such as prevention of crises with proactive approaches and crisis communication.

\section{References}

1. M. Eğilmez, AKP'nin On Yılının Ekonomik Değeri, Available at: http://www.mahfiegilmez.com/2013/01/ akpnin-on-ylnn-ekonomik-resmi.html, Accessed: 8 July 2013.

2. N. Ilicak, AK Parti'nin Karnesi, Available at: http://www.sabah.com.tr/Yazarlar/ilicak/2012/12/12/akpartinin-karnesi Accessed: 5 July 2013.

3. K. Tayfur, Yeryüzü Çocukları, Atlas Aylık Coğrafya ve Keşif Dergisi, 7(2013) 37-56.

4. Sabah, Belediye Meclisi'nden oy birliği ile geçti, Available at: http:/www.sabah.com.tr/Gundem/2013/06/ 01/belediye-meclisinden-oy-birligi-ile-gecti, Accessed: 5 July 2013.
5. Hürriyet, Gezi Parkı'ndaki 'kavga'nın sebebi AVM planı, Available at: http://www.hurriyet.com.tr/ekonomi/23405 125.asp, Accessed: 9 July 2013.

6. K. Çalışlar, Gezi Parkı alışveriş merkezi, Available at: http://www.radikal.com.tr/yazarlar/koray_caliskan/gezi parki_alisveris_merkezi-1131582, Accessed: 5 July 2013.

7. Z. Toprak, Yerel Yönetimler ve Sivil Toplum, Ortadoğu ve Sivil Toplum Diyalogu Çalıştayı, 6-7 April 2013, Gaziantep.

8. K. Tayfur, Gezi Parkı Kitlelerin Evi, Atlas Aylı Coğrafya ve Keşif Dergisi, 7(2013) 70-76.

9. T. Şardan, 2.5 milyon insan 79 ilde sokağa indi, Available at: http://gundem.milliyet.com.tr/2-5-milyoninsan-79-ilde-sokaga/gundem/detay/1726600/default. htm?ref=haberici, Accessed: 10 July 2013.

10. N. Demir, Türk Kamu Yönetiminde Kriz Yönetimi, İçişleri Bakanlığı Personel Genel Müdürlüğü Kaymakamlık Tezi, Ankara, 2011.

11. A. Ş. Özcan, Afet ve Acil Durum Yönetimi Mahiyeti, İlgili Kurumları ve Kapsam1, İdarecinin Sesi, 144(2011) 11-16.

12. Ş. Erten, Türk Kamu Yönetiminde Kriz Yönetimi Anlayışı, Süleyman Demirel Üniversitesi Sosyal Bilimler Enstitüsü Yüksek Lisans Tezi, Isparta, 2011.

13. A. Ekşi, Nükleer Kaza ve Saldırılarda Bütünleşik Kriz Yönetimi, Dokuz Eylül Üniversitesi Sosyal Bilimler Enstitüsü Doktora Tezi, İzmir, 2013

14. M. Tyrone, Crisis Communication: A Commanders Guide To Effective Crisis Communicatio, Air Command And Staff College Air University, Alabama, 1998.

15. NHPCO, Crisis Communications Planning A Guide for Providers, Available at: http://www.nhpco.org/files/publ ic/communications/crisis_guide.pdf, Accessed: 8 July 2013.

16. T. Akyol, Olaylardan Dersler, Available at: http://www.hurriyet.com.tr/yazarlar/23421681.asp, Accessed: 6 July 2013.

17. Milliyet, Bülent Arınç'tan 'Gezi Parkı' açıklaması, Available at: http://siyaset.milliyet.com.tr/bulent-arinctan-gezi-parki-/siyaset/detay/1717157/default.htm, Accessed: 8 July 2013.

18. R. Brewster, Natural Disaster Recovery Planning, University of Technology, Kingston, 2005.

19. M. Kadığlu, Afet Yönetimi Beklenilmeyeni Beklemek En Kötüsünü Yönetmek, T.C. Marmara Belediyeler Birliği Yayını, İstanbul, 2011,

20. H.H. Güler, Zarar Azaltmanın Temel İlkeleri, in Kadıŏlu, M. and Özdamar, E. (Ed.), Afet Zararların Azaltmanın Temel Ilkeleri, JICA Türkiye Ofisi Yayınları No: 2, Ankara, 2008, pp. 35-50.

21. S. Bilgen, Katılımcilık ve Temsiliyet, Available at: http://www.oed.org.tr/oed/images//katilimciliktemsiliyet.pdf, Accessed: 7 July 2013.

22. A. Özyol, Sürdürülebilir Kalkınma ve Katılımcı Demokrasi, Available at: http://www.bpwturkey.org/eklentiler/surdurulebilirkalkinmavekatilimcid emokrasi.doc, Accessed: 7 July 2013.

23. Z. Toprak, Algıla seçicilik ve ekoloji, Available at: http://www.kazete.com.tr/makale_Algida-secicilik-veekoloji_853.aspx, Accessed: 6 July 2013. 
24. S.S. Alıca, (2011), 'Cevresel Etki Değerlendirmesinin Yargı Kararları Çerçevesinde İrdelenmesi’, Gazi Üniversitesi Hukuk Fakültesi Dergisi, Volume 11, Number 3, pp. 97-130.

25. Chamber of Environmental Engineers, ÇED Yönetmelik Değişikliği Üzerine Açılama, Available at: http://www.tmmob.org.tr/genel/bizden_detay.php?kod= 8963\&tipi=9, Accessed: 6 July 2013.

26. Art1 Ivme Magazine Urban Transformation Commission, Akp'nin Çılgin Projeleri ve ÇED Engeli, Artı İvme Dergisi, Available at: http://www.Ivmedergisi.Com/ Akp $\%$ E2\%80\%99nin-\%C3\%A7ilgin-Projeleri-Ve\%C3\%A7ed-Engeli.Html, Accessed: 5 July 2013.

27. Enerjiline, Artık ÇED Raporu İstenmeyecek, Available at: http://www.enerjiline.com/haberdetay/Artik-CEDRaporu-Istenmeyecek/544, Accessed: 6 July 2013.

28. R. Demir, Yerel Yönetimlerde Halkın Yönetime Katılımı, Yönetim ve Denetim Dergisi, 11(1) (2006) 6073

29. Z. Aras and E.B. Altınok, Türkiye'de Bilgi Edinme Hakk1 ve Uygulama Sorunlar, Ankara Barosu Dergisi, 67(1) (2009)107-112.

30. S.Y. Koçak, Kamu Yönetiminde Açılklı İçin Bilgi Edinme Hakk1, Selçuk Üniversitesi Sosyal Bilimler Enstitüsü Dergisi, 23(2010) 115-125.

31. A. T. Özdemir, Mahalli İdarelerde Halk Katılımı Bağlamında Kent Konseyleri, Sayıștay Dergisi, 83(2011) 31-56.

32. S. Cengiz, Avrupa Insan Haklarl Mahkemesi Karart Ișı ğında Bergama Davası, http://www.inisiyatif.net/ document/12.asp, Accessed: 7 July 2013.

33. R. Türmen, Çoğulcu ve katılımcı demokrasiye doğru, Available at: http://gundem.milliyet.com.tr/cogulcu-vekatilimci-demokrasiye/gundem/ydetay/1722280/default. htm, Accessed: 6 July 2013.

34. European Commission, Türkiye 2012 Yll Ilerleme Raporu, Available at: http://www.abgs.gov.tr/files/ strateji/2012_ilerleme_raporu.pdf, Accessed: 6 July 2013.

35. P. Cengiz, Çılgın proje Avrupalı Yeşiller'in markajında, Available at: http://www.taraf.com.tr/pelin-cengiz/ makale-cilgin-proje-avrupali-yesiller-in-markajinda.htm, Accessed: 6 July 2013.

36. C. Akgüloğlu, 4+4+4 dindar neslin doğuşu, Available at: http://www.radikalgenc.com/politika/444-dindar-neslindogusu, Accessed: 5 July 2013.

37. İ. Çoşkun, 4+4+4 dindar nesil yetiştirme projesi mi? Available at: http://www.sabah.com.tr/Perspektif/ Yazarlar/icoskun/2012/09/08/444-dindar-nesilyetistirme-projesi-mi, Accessed: 7 July 2013.

38. Milliyet, Erdoğan: Kürtaj bir cinayettir, Available at: http://siyaset.milliyet.com.tr/erdogan-kurtaj-bircinayettir/siyaset/siyasetdetay/26.05.2012/1545254/defa ult.htm, Accessed: 9 July 2013.

39. N. Y1lmaz, Yavuz Sultan Selim Alevileri Katletti mi? Available at: http://www.internethaber.com/yavuzsultan-selim-alevileri-katletti-mi-541047h.htm, Accessed: 10 July 2013.

40. Dogan News Agency, Alevi Dernekleri 3. Köprü İsmine Tepki Gösterdi, Available at: http://www.haberler.com/ alevi-dernekleri-3-kopru-ismine-tepki-gosterdi4697428-haberi/, Accessed: 8 July 2013.

41. A. Öymen, Alkol için iki ayrı söylem, Available at: http://www.radikal.com.tr/yazarlar/altan_oymen/alkol_ic in iki ayri_soylem-1135390, Accessed: 11 July 2013.

42. GĒNAR, Gezi Parkı Profili, Available at: http://www.genar.com.tr/files/GEZIPARKI_PROFILSON.pdf, Accessed: 9 July 2013.

43. H. Hacaloğlu, Taksim Gezi Parkı'nda Polis Müdahalesi, Available at: http://www.amerikaninsesi.com/content/ taksim-gezi-parkinda-polis-mudahalesi/1672061.html, Accessed: 6 July 2013.

44. İ. Berkan, Esas orantısız güç kullanımı, Available at: http://www.hurriyet.com.tr/yazarlar/23501729.asp, Accessed: 8 July 2013.

45. Vatan, Ben öyle bir Kabataş videosu görmedim, Available at: http://haber.gazetevatan.com/ben-oyle-birkabatas-videosu-gormedim/553520/1/gundem, Accessed: 12 July 2013

46. T. Bengin, Hani istihbarat gelmisti, Available at: $\mathrm{http} / /$ gundem.milliyet.com.tr/hani-istihbarati-gelmisti/gundem/ydetay/1730225/default.htm, Accessed: 7 July 2013.

47. A. Bayramoğlu, Bir demokrasi krizi olarak Gezi, Available at: http://yenisafak.com.tr/yazarlar/AliBayra moglu/bir-demokrasi-krizi-olarak-gezi/38243, Accessed: 9 July 2013.

48. Anadolu Agency, Gezi Parkl ile ilgili mahkemeden karar, Available at: http://www.haber7.com/guncel/ haber/1033404-gezi-parki-ile-ilgili-mahkemeden-karar, Accessed: 6 July 2013.

49. Akşam, Başbakanlıkta Gezi Parkı zirvesi, Available at: http://www.aksam.com.tr/siyaset/basbakanlikta-geziparki-zirvesi-iste-aciklamalar/haber-215602, Accessed: 7 July 2013.

50. M.A. Berber, Ihanetin sebekesini milletimize açıklayacă̆ız, Available at: http://www.sabah.com.tr/ Gundem/2013/06/16/ihanet-sebekesini-milletimizeaciklayacagiz, Accessed: 6 July 2013.

51. M. Alphan, Milli irade, http://www.hurriyet.com.tr/ yazarlar/23545140.asp, Accessed: 5 July 2013.

52. E. Kongar, Gezi Parkı ve Nefret Suçlarl, Available at: http://www.cumhuriyet.com.tr/?hn=427004\&kn=37\&ka $=4 \& \mathrm{~kb}=5 \& \mathrm{kc}=37$, Accessed: 11 July 2013 .

53. KONDA, KONDA anketine göre Gezi Parkl, Available at: http://www.aksam.com.tr/guncel/konda-anketine-go re-gezi-parki/haber-215337, Accessed: 10 July 2013.

54. M. Yilmaz, Gezi olaylarında otosansür habercilik refleksini bastırdl, Available at: http://www.medyagun lugu.com/ozelhaber/473-otosansur-habercilik-refleksinibastirdi.html, Accessed: 11 July 2013.

55. B. Akçura, Günümüz medyasında sansür ve otosansür, Available at: http://www.milliyet.com.tr/gunumuzmedyasinda-sansur-ve/ombudsman/haberdetay/10.06.20 13/1720764/default.htm, Accessed: 6 July 2013.

56. Vatan, NTV'de büyük protesto, Available at: http://haber.gazetevatan.com/ntvde-buyukprotesto/543260/1/gundem, Accessed: 9 July 2013.

57. Anadolu Agency, Mahkemenin karart isabetli, Available at: http://www.ntvmsnbc.com/id/25446574/, Accessed: 8 July 2013. 
58. Anadolu Agency, Bülent Arınç'tan Gül görüşmesi sonrası Gezi Parkl Özrü, Available at: http://gundem.bugun.com.tr/hukumet-ozur-diledihaberi/651420, Accessed: 7 July 2013.

59. Ü. Kılınç, Orantısız güç AIHHM'den döner, Available at: http://www.radikal.com.tr/radikal2/orantisiz guc aihmd en_doner-1139892, Accessed: 8 July 2013.

60. M.A. Şahin, Gezi Parkı eylemlerinin sebebi ă̆aç değil, darbeye zemin hazırlamak, Available at: http://t24.com.tr/haber/mehmet-ali-sahin-gezi-parkieylemlerinin-sebebi-agac-degil-darbeye-zeminhazirlamak/231114, Accessed: 8 July 2013.

61. M. Çubukçu, Gezi'deki dış güçler, Available at: http://www.radikal.com.tr/radikal2/gezideki_dis_gucler1137599, Accessed: 8 July 2013.

62. Cumhuriyet, Dayanışma Yasa Dışı Örgüt oldu, Available at: http://www.cumhuriyet.com.tr/?hn $=428052$, Accessed: 6 July 2013 .

63. Radikal, Taksim Dayanışma serbest, Available at:http://www.radikal.com.tr/turkiye/taksim dayanisma serbest-1141451, Accessed: 11 July 2013.

64. Ihlas News Agency, TMMOB'dan Basın Açılaması, Available at: http://www.haberler.com/tmmob-danbasin-aciklamasi-4818748-haberi/, Accessed: 5 July 2013.

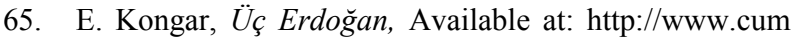
huriyet.com.tr/?hn=425192\&kn $=37 \& \mathrm{ka}=4 \& \mathrm{~kb}=5 \& \mathrm{kc}=3$ 7, Accessed: 11 July 2013.

66. Dogan News Agency, Nabi Avci'dan Gezi Parkı olaylar için dikkat çekici yorum, Available at: http://www. aksam.com.tr/siyaset/nabi-avcidan-gezi-parki-olaylariicin-dikkat-cekici-yorum/haber-211903, Accessed: 6 July 2013.

67. E. Kongar, AKP'nin Büyük Bașarısl, Available at: http://www.cumhuriyet.com.tr/?hn=425192\&kn=37\&ka $=4 \& \mathrm{~kb}=5 \& \mathrm{kc}=37$, Accessed: 11 July 2013 .

68. M. Sarıkaya, 2014 seçim senaryolarl, Available at: http://www.haberturk.com/yazarlar/muharremsarikaya/846158-2014-secim-senaryolari, Accessed: 11 July 2013 